\title{
POU5F1 Gene
}

National Cancer Institute

\section{Source}

National Cancer Institute. POU5F1 Gene. NCI Thesaurus. Code C61140.

This gene plays a role in early mammalian development. 